\title{
Controlling the pollution trade
}

Under a unique treaty which entered into force last month, private citizens living in the Nordic area will have the right to complain about and be compensated for damage to their environment caused by activities in their neighbouring countries. Mike Duckenfield reports

THAT the first agreement of its type should be reached between the Nordic nations is no surprise. Norway, in particular, suffers badly in the present European exchange of pollution and the Scandinavians as a whole are keen to secure international consensus on its control. In deciding to put their own house in order they are not only showing their seriousness, but aiming to preempt any criticisms about their own lack of action.

The agreement, prompted by the Nordic Council and covering all five of its members except Iceland, will be supplemented next January by Norwegian legislation requiring industry to use low-sulphur fuels. In October next year a start is due to be made to a seven-year Swedish plan to cut sulphur emissions to their level in the early 1950s.

The Swedish plan follows a recent government commission appointed by the Minister of Agriculture which carried out an extensive survey of air pollution problems caused by the burning of fossil fuels containing sulphur. It estimated that in 1973 about $60 \mathrm{mil}$ lion tons of sulphuric fallout, either dry or in precipitation, was generated in Europe, compared with only 25 million tons between 1910 and 1950. Of this, 38 million tons came from Eastern Europe and the remainder from the West. In addition, increased energy consumption in all countries was expected to result in the generation of $74 \mathrm{mil}$ lion tons by 1985 , with 27 millions tons coming from the West.

In 1974, Sweden itself burned about 19 million tons of fuel oil, two-thirds of it heavy. As oil with a sulphur content of $2.5 \%$ by weight causes emissions of about $50 \mathrm{~kg}$ of sulphur for every ton of oil burned, it was calculated that about 800,000 tons of sulphur was emitted, a quarter of it from industrial processes using sulphuric compounds and the remainder from burning oil. If no action was taken this would rise to one million tons by 1985. As it is, the aim is to cut it to 300,000 tons.

To achieve this the Swedish plan involves banning the import and sale of light fuel with more than $0.5 \%$ sulphur nationally from next October and, at the same time, prohibiting the use of heavy oil with more than $1 \%$ sulphur in the part of the country south of a line north-west of Stockholm. Two years later, the ban would extend to light oils with more than $0.3 \%$ sulphur and, in 1981, the extension nationally of the heavy oil ban. The plan also requires that the existing ban on burning oil with more than $2.5 \%$ sulphur be placed on other fossil fuels, most notably coal.

The programme would cost an estimated 500 million Swedish crowns (about $£ 72$ million) and includes government grants to finance the experimental liming of some of the 10,000 or so lakes that have been acidified by sulphuric fallout. At present it costs between Skr 400 and Skr 500 per hectare to lime the lakes and the job has to be repeated every five years.

For all this, Sweden expects to be able to do no more than maintain the starus quo in the worst affected southern and western parts of the country. The reason is simply that most of the pollution is imported, mostly from the south and west across the North Sea and Baltic. In these areas it is estimated that less than 25 per cent of the fallout is Swedish in origin. In the remainder of the country the figure varies from between a quarter to a half of the total. Nationally it is just short of one-third. Because of this, the Swedes would now like to see total emissions in Western Europe brought down to between six and eight million tons within the next 10 years, a task that would cost about $\mathrm{Skr} 20,000$ million a year.

In neighbouring Norway the situation is even worse with less than onetenth of fallout being home-produced. Even in the area around Oslo, the country's most industrialised region, the figure only reaches $30-40 \%$. The thin soil over much of the country does little to neutralise the acid rain and the build up of polluted winter snow leads to an annual mass slaughter of thousands of hatching and spawning fish when the spring thaw pours into the rivers and lakes. In the worst-hit south-west salmon and trout have disappeared from many rivers and a recent survey of 153 previously well-stocked lakes revealed the eradication of all types of fish from all but two of them.

So serious has the problem become that the Norwegian government is currently spending about $\mathfrak{£ 6 . 5}$ million in employing 60 full-time scientists on a seven-year programme to examine the effects of acid precipitation. And to draw international attention to the need for control, the Norwegian Ministry for the Environment together with the precipitation project (SNSF project) this summer invited representatives from 20 nations including all but Luxembourg of the Common Market countries, the Soviet Union and three Eastern European nations to a conference at Gaustadblikk near Rjukan in Telemark in the south-west.

Research shows that not only are fish being killed, but acid rain is affecting soil productivity and could be causing decreased forest production due to the depletion of the earth's nutrients. Similarly, the Swedish commission report also points to the effects on urban areas due to the corrosion of metals and stone, especially limestone and marble. Costs of quicker replacement of materials and the need for corrosion protection were put at anywhere between Skr 100 million and Skr 1,000 million annually, not including the irreplaceable damage done to historic buildings and monuments.

While the conference could only agree to recommend nations to reconsider their approaches to emission control and to sponsor more research, international cooperation may be given a much needed boost with the publication of a report by the Organisation for Economic Co-operation and Development next year. OECD's recently completed research project into the long-range transport of air pollutants will show just how badly affected southern Scandinavia is. In one extreme case in January 1974, winds from all over Europe brought 4,000 tons of sulphate and dumped it over about 20,000 square $\mathrm{km}$ of southern Norway in just 12 days. Some areas had nearly a ton of sulphate per square kilometre.

\section{Sorry, for copyright reasons some images on this page may not be available online}

